\title{
THEORETICAL PRINCIPLES OF USING STEAM-TECHNOLOGIES IN THE PREPARATION OF THE TEACHER OF THE NEW UKRAINIAN SCHOOL
}

\author{
OLENA BUDNYK
}

\begin{abstract}
The Urgency of the problem of STEAM-education, need for training of relevant specialists, especially teachers for using modern digital technologies in the process of teaching students, orientation of the younger generation on STEM professions are discussed in the article. The essence of the digital competence of a modern specialist, which includes a system of knowledge and skills according to the conscious, responsible and critical use of digital technologies in the process of educational and labour activity, civil or social activity is defined by the author. It is revealed that the teacher's digital competence is manifested in his/her information literacy, culture of using data, communication in the information space, the ability to create relevant digital content. Theoretical principles of the introduction of innovative technologies in the pedagogical process of the New Ukrainian school are described. The forms and methods of using STEAMtechnologies in a modern educational establishment are presented. The author stresses there is a need to use various learning tools during the work with students: presentations, laboratory tutorials and simulations, discussions, and peer collaboration to support learning activity, exploration, etc.
\end{abstract}

Keywords: STEAM-education, digital competence, innovative educational technologies, elearning, modern teacher.

\section{INTRODUCTION}

Today in the world there is an urgent need of specialists in the scientific and engineering spheres, IT technologies to ensure the growth of economy and technological progress. Though, the future society will rely on information and communication technologies more and more: web-technology, cloudy calculation of big data, smartphones, the Internet and other gadgets. The technological progress that require lifelong learning must be based on "strong collaboration and synergies between industry, education, training and learning settings" [5]. In this context, the problem of STEM-education, training relevant specialists, especially teachers for the using of modern digital technologies in teaching students, their orientation towards the STEM profession is relevant.

STEM \& STEAM. In the context of the problem of the synthesis of science and art in the STEMeducation, we have a tendency for the rapid development of creativity, which includes artistic and creative trends (architecture, industrial design, industrial aesthetics, etc.). Therefore, in the field of 
STEM, which serves as the basis for the training specialists for high technologies, the development of students' creativity and the representation of Arts-disciplines in the content of their preparation is defined as a strategic point. Its evidence, is for example the fact that in the state of Massachusetts (MA, USA) Public Schools for Developing an Index of Creative and Innovative Education are conducting the rating. Today it is extremely important in the behaviour of pupils to use the analytical, creative skills in solving the problem in the field of science, mathematics, reading and writing (students apply analytical, creative, and problem-solving skills in science, mathematics, reading, and writing), the development of "innovative talent to meet the needs of its business community" [13].

In the researches of scientists (A. M. Connor, S. Karmokar, Ch. Whittington; 2015) the minds about the need to integrate STEM disciplines and arts into a broader educational context (STEAM) [2]. After all, natural sciences, technology, engineering, art, mathematics as a system of education involves mastering primarily technological competencies and is aimed at the development of scientific and technical creativity of students. Though technological trends cannot be developed today without such skills as teamwork, creativity, global awareness, financial literacy, aesthetic awareness, critical thinking and etc.

Many well-known foreign scientists work to stimulate the scientific and cognitive interests of young people while at the same time they are trying to overcome gender stereotypes about inaccessibility or difficulty for girls (women) STEM-technologies (mathematical and natural sciences, engineering, robotics and etc.). Australian women scientists, for example, are trying to dispel these assumptions about women in STEM, and in the concrete examples explain their ability to pursue academic careers in relevant areas, solving the issues of gender equity and diversity [18]. After all, every student should have access to STEM's high-quality educational facilities and it does not depend on the place of residence, ethnicity, race or gender.

J. Rodriguez \& I. E. Esparragoza (2017) investigated the level of motivation of student engineers before the participation in project activities on a gender basis: male students are more persistent in making decisions in the joint activities, and female students have shown greater interest in the learning material. It has been found that "female students give more value to this academic activity than men, or just that they are more responsible" [17, p. 82], "although the average level of intrinsic motivation of students is similar, despite their gender, case female students' responses show more variability, with similar tendency for perceived choice and competency constructs" [17, p. 83]. At the same time, students, regardless of gender, have a high level of motivation and competence in engineering (J. Rodriguez, I. E. Esparragoza). So, it can be argued that the gender stereotypes need to be overcome from the point of view of the fact that the STEM specialties concern more boys than girls. In this context, it is obviously that the formation of digital literacy and information and communication culture are relevant, development of STEM-education programs for girls, who are marked by special care and patience in the work.

\section{ANALYSIS AND DISCUSSION}

\subsection{Digital Literacy OF A MODERn TeACHeR}

Digital competence is a key competence that is needed for a modern person "for personal fulfillment and development, employment, social inclusion and active citizenship" [5]. "In particular, the ubiquity of digital devices and duty to help students become digitally competent requires educators to develop their own digital competence. On the international and national level, a number of frameworks, self-assessment tools and training programs have been developed to describe the facets of digital competences for educators and to help them assess their competence, identify their training needs and offer targeted training" [6].

The digital competence of a modern specialist includes a system of knowledge and skills in the conscious, responsible and critical use of digital technologies in the process of educational and labour activity, civil or social activity. It is information literacy, the culture of using data and communication in the information space, the ability to create relevant digital content. At the same time, rapid 
development of digital technologies requires purposeful preparation of a person, first of all for useful and safe using of them. It also deals with imperfect protection of a young person from digital content that may harm his/her physical, mental or social health and development, lack of mechanisms for effective self-regulation of the information market, in order to prevent the consumer from being subjected to an inferior product, socially harmful information influences, etc. It is not casually that in the "Concept for the Implementation of Media Education in Ukraine" (2010) the main tasks are "the promotion of media literacy, media immunity, reflection and critical thinking, and media literacy" [12].

Digital competence also predicts the awareness of legal and ethical principles according to using of various electronic resources, digital technologies, ability to have a critical attitude to reliable received information, proper using of digital media for reaching of personal, professional or social purposes.

In today's higher education, the role of information technologies in the context of the European Area of Higher Education is actively examined, active methods of teaching students are promoted, which motivates them for the creative and research activity, as opposed to the traditional lectures or seminars of the reproductive character [9]. The technologies of "active" learning include orientation towards the cognitive needs and interests of the pupil (student) in mastering the knowledge, the socalled principle of human (child-centrism) in the education [11], although in the educational practice there is often a lack of acceptance of such student-centered approaches (of student centric practices) [3]. Innovative technologies of high school education that are based on the student centrism principles, in most cases are related to STEM disciplines.

In this regard, scientists of Vasyl Stefanyk Precarpathian National University has started active work within the framework of the EU program Erasmus + KA2 - Capacity building in Higher Education with the project "Modernization of Pedagogical Higher Education by Innovative Teaching Instruments (MoPED)" - №586098-EPP-1-2017 -1-UA-EPPKA2-CBHE-JP, which will last for 3 years (2017-2020). Its main aim is modernization the curriculum of higher educational establishments in Ukraine by introducing modern teaching methods, STEAM disciplines using information and communication technologies. MoPED is aimed at the improving the quality of education degree, the development of digital and didactic competence of future teachers in the context of the new Ukrainian school.

The innovative teaching methods in the training of a teacher are: e-learning, online environment, mobile learning, etc. [20]. Teaching online is a new form of work with students in a New Ukrainian school. At the same time, this is a different experience from the teaching of a face-to-face setting. Therefore, the development of training and methodological support for teaching online requires a special training of a teacher and students. Today, there is a problem in the training of specialists for the use of information technologies in teaching STEM subjects for elementary and secondary schools (natural sciences, mathematics, science, technology), because of such online courses require hands-on activities, laboratory works and live demonstrations.

Training of the teacher to familiarize the pupils with scientific and engineering fields, IT technologies and others and it involves the mastering of new concepts such as STEM- \& STEAMeducation, STEAM literacy, engineering, reengineering, nanotechnology, robotics, online environment, e-learning, m-learning, u-learning, f-learning, blended-learning, creative industry, mechatronics, fundraising, online discussion forum, digital literacy, information culture and others.

At the same time, STEAM-technologies are mainly focused on secondary education. We consider it is more important to develop among the students the so-called pre-conditions for successful technological knowledge even in elementary school. Early involvement of children in STEAM serves not only as a means of developing creative thinking, forming the competence of the researcher, but also contributes to their socialization, helping them choose their future profession. Interactive studying develops such skills as: collaboration, communication, teamwork, creativity. For the development of gifted children, starting with preschool and junior school age, it is advisable to use STEAM's online learning environment to build skills in design, cooperation, communication and critical thinking based on a multidisciplinary approach. 
Though, today for e-learning you can take advantage of the extensive collection of online labs, interactive inquiry, combine labs and apps into Inquiry Learning Spaces (ILS), etc. (http://www.golabz.eu/). ILS are personalized learning resources for students, where they can conduct scientific experiments, get new knowledge by themselves, develop research skills. Unfortunately, on this platform, most ILSs are English (197), Portuguese (98), Spanish (56). Therefore, there is a problem of creating a research environment using modern teaching tools for Ukrainian students (http://www.golabz.eu/spaces).

In schools abroad (USA, Canada, UK, etc.) students are offered the focused programs in the field of health sciences, ecology, computer and communication technologies, etc. For this purpose, the cooperation of schools with future employers, such as "Lego", "Lenovo" and others is practiced.

In our context, the forming of designing skills and research activities are provided by LEGO Education courses and programs. The integrated education system is the basis for the activities of the New Ukrainian School [15]. In the elementary classes, today are considered possible options for integrating LEGO techniques in the pedagogical process. For example, it is advisable to combine the study of individual topics in mathematics and robotics, science and technology with the use of LEGO as a means of forming critical thinking and developing the skills of scientific and research activity.

A logical continuation of the student's learning activity during the lessons is an extra-curricular educational work, which is less regulated in time and gives more opportunities for creative projects. Therefore, it is more important to consider the use of STEM elements in the work of sections, societies, day off clubs by involving children and parents in design and research activities. After all, STEM is a team work and it is aimed at integrating natural and mathematical knowledge into the system of relevant competencies. Modern pupils are interested in designing, programming, modeling, 3Ddesigning, robotics, etc. Therefore, in order to satisfy their cognitive needs, it is necessary to create a developed educational online environment that would contribute not only to the development of complex skills and competences, but it also could concuss to the creative searches, inventions.

In modern conditions, there is a tendency when the teachers and students not always show the wish or are interested to work on the integrated teaching methodology. Therefore, there is the notion of "disciplinary egocentrism" (D. M. Richter, M. C. Paretti, 2009) [16]. "Disciplinary egocentrism encompasses two factors, a negative relatedness and a negative perspective. The first one is a failure to see connections between a given discipline and an interdisciplinary subject or problem, which limits the ability to incorporate new ideas and practices. The second aspect is not only a rejection of other viewpoints, but often a failure to recognize the differences in perspectives and contributions. It is quite likely that disciplinary egocentrism is as much present in academic staff as a student body and that this may be a factor in the slow adoption of new pedagogies in any discipline" [2].

An extremely important tendency in pedagogical science and practice is the use of STEAMeducation to teach children with peculiarities of psychophysical development. After all, among them there are also gifted children who have certain opportunities for the appropriate kind of activity. Thanks to the powerful development of digital technology, there are a variety of assistive technologies (AT) that "used to refer to a group of software or hardware devices that people with disabilities can access computers ... Assistive technology can include devices such as alternate keyboards and mice, voice recognition software, monitor magnification software, multiple switch joysticks, and text-tospeech communication aids" [1].

Today in the world there are many specialists in IT technologies field of that have limited health opportunities. Moreover, the effective aspect of inclusive education is the identification and recognition of the compensatory possibilities of people with disabilities, who despite the nosology, have abilities and talents, first of all, to activities that require independent search work, inventiveness, assiduity, patience, etc. Actually, this is STEAM-education research that predicts e-learning, learning spaces, mobile learning, and others [20].

Foreign practice certifies the effectiveness of integrated training also in university education. Andy M. Connor, Sangeeta Karmokar, and Chris Whittington (2015) emphasize that "the tenets of the STEAM movement can be adopted in tertiary education where modularization and semesterization can 
produce barriers to an integrative curriculum" [2, p. 37]. The idea of teaching students with the application of interdisciplinary and applied methods is popular. It is no coincidence that many modern researches are devoted to this problem (Andy M. Connor, Sangeeta Karmokar, Chris Whittington, 2015), especially the using of project methodology in the study of integrated courses in engineering education [2].

The authors define three types of projects that differ in the degree of student autonomy [2, p. 38]:

1. Task project: Student teams work on the projects that have been defined by the instructor using largely instructor-prescribed methods. This type of project provides for minimal student motivation and skill development, and is part of the traditional instruction in most engineering curriculum.

2. Discipline project: The instructor defines the subject area of the projects and specifies in general terms the approaches to be used (which usually involve methods common in the subject area discipline), but students identify the specific project and design the particular the approach they will take to complete it.

3. Problem project: The students have almost complete autonomy to choose their project and their approach to it.

We consider it reasonable to use this method in teaching teachers to teach STEAM subjects in a secondary school. It is important to involve students in cooperative learning, teamwork, where they can share their thoughts, apply new knowledge for a deeper understanding of the problem (Miller \& Redman, 2010) [14].

So an effective form of on-line learning is the student's project activity. In particular, "mini projects were found to be one of the most effective strategies to complete the final project. Mini projects allow students time to master specific concepts and skills, such as checking initial data and forming a research question while internalizing learning" [21]. Actually, mini project helps in the real using of gained knowledge and its integral representation.

To study STEAM disciplines at a higher educational establishment, in particular for a better understanding of complex topics, scientific concepts, students need to exchange their gained knowledge, experiment and discuss specific research situations. The scientific researches have shown the effectiveness of high-quality online experiential learning interactions, which includes asynchronous discussion forums and synchronous sessions in Skype (chat, audio, and document sharing) (Strang, 2012) [19].

According to Dazhi Yang (2017), such an important method as the online discussion forum allows students to "discuss course-related questions, an informal type of peer collaboration." "The online discussion provided a place for students to post their questions and issues and also helped promote a sense of social presence and a sense of contributing to the class by providing responses to peers' questions and sharing helpful resources." As it is noted, that "online discussions are important in an online statistics class" [21].

Another method that helps apply new knowledge about STEAM is subjects in specific situations of real life, in particular in the practice of school work, is case study. "Case studies are in-depth investigations of a single person, group, event or community. Typically, data are gathered from a variety of sources and by using several different methods (e.g. observations \& interviews)" [10]. The case-study method is a tool that promotes the development of independent thinking of students, ability to express their thoughts reasonably, listen and take into account an alternative point of view. With this method, students have an opportunity to demonstrate and improve their analytical and assessment skills, and find the best solution to the problem. It is important that this is a method of active learning, and a well-organized discussion of a case is usually emotional and reminds a theatrical performance. However, debate discussions are quite realistic to be performed online. At the same time, the effectiveness of online courses will increase if the teacher plans at least one or two virtual meetings in order the whole group could contact on a specific topic.

Another important form of using Internet resources in teaching students of pedagogical major is the involvement of them in the creation of their own on-line resources, simulation of on-line courses for elementary or secondary school students under the curriculum STEAM-subjects, which will be studied in accordance with the Concept of the New Ukrainian School [15]. This is important in the context of training teachers to 
work with online resources, as well as the formation of constructive skills and qualifications in the modeling of the educational developed environment at school.

In the context of creating online courses or individual elements of research training for teachers who will teach STEAM-subjects in elementary or secondary school, it is important to use a variety of learning tools, including presentations, laboratory tutorials and simulations, discussions, and peer collaboration to support learning activity, exploration, which will help themselves gain new knowledge (Juan et al., 2011) [7]. An important aspect of creating a learning research environment with STEAM subjects is the peculiarities of its design, including video design.

\section{CONCLUSIONS}

Today, in the domestic education, STEAM-technologies are represented in various forms: educational competitions, activities of non-school education establishments (for example, the network of technical studies "Inventor") especially hobby groups, "Lego" and "Robototechnics", the contests IntelTechnoUkraine, IntelEcoUkraine, FirsLegoLeague competitions and WorldRoboticOlympiad, Science Festivals SikorskyChallenge, scientific picnics, hackathons, etc. A positive phenomenon is the discovery of interactive scientific museums, technical entertainment centers, MiniEdCamp for children and youth. This motivates young people to study STEAM disciplines. However, in today's conditions of informatization of society there is a problem of the formation and development of digital competence of each person, and it does not depend on his/her sphere of employment. Therefore, it is important to start the purposeful introduction of innovations, begining with elementary school. First of all, it concerns STEAM education, which is given a priority place at the New Ukrainian school.

Obviously, at the time of development of strategic approaches according to the implementation of STEAM education, we are sure to take into account the progressive foreign experience, focused systemic work on promotion and implementation of STEAM technologies in domestic educational establishments of different types, prepare teachers for using of pedagogical innovations, digital educational content, adapt organizational, content, information and technological support of this process, taking into account the innovative teaching tools and others like that.

\section{REFERENCES}

[1] Assistive technology. Available at: https://www.webopedia.com/TERM/A/assistive_technology.html.

[2] Connor A.M., Karmokar S., Whittington C. From STEM to STEAM: Strategies for Enhancing Engineering \& Technology Education. International Journal of Engineering Pedagogy, 5 (2) (2015), 37-47.

[3] DeHaan R.L. The impending revolution in undergraduate science education. Journal of Science Education and Technology, 14 (2005), 253-269. Available at: http://dx.doi.org/10.1007/s10956-005-4425-3.

[4] Digital agenda of Ukraine - 2020. Available at: https://ucci.org.ua/uploads/files/58e78ee3c3922.pdf. (in Ukrainian)

[5] European commission. Proposal for a Council Recommendation on Key Competences for Lifelong Learning. Brussels, 17.1.2018. Available at: https:/ec.europa.eu/education/sites/education/files/recommendationkey-competences-lifelong-learning.pdf.

[6] Redecker C. European framework for the digital competence for educators: DigCompEdu. Publications Office of the European Union, Luxembourg, 2017. Available at: http://dx.doi.org/10.2760/159770.

[7] Juan A.A, Steegmann C., Huertas A., Martinez M.A, Simosa J. Teaching mathematics online in the European area of higher education: an instructor's point of view. International Journal of Mathematical Education in Science and Technology, 42 (2) (2011), 141-153. Available at: https://doi.org/10.1080 /0020739X.2010.526254. 
[8] Havrilova L.H., Topolnik Ya.V. Digital culture, digital literacy, digital competence as the modern educational phenomena. Information Technologies and Learning Tools, 61 (5) (2017), 1-13. (in Ukrainian)

[9] Lord T.R. A comparison between traditional and constructivist teaching in college biology. Innovative Higher Education, 21 (1997), 197-216. Available at: http://dx.doi.org/10.1007/BF01243716.

[10] McLeod S.A. Case study method. SimplyPsychology, 2008. Available at: www.simplypsychology. org/case-study.html.

[11] Kremen V.H. Philosophy of human-centeredness in the educational space. Company "Knowledge" Ukraine, Kyiv, 2011. (in Ukrainian)

[12] Concept of implementation of media education in Ukraine (new edition), 2016. Available at: http://osvita.mediasapiens.ua/mediaprosvita/mediaosvita/kontseptsiya_vprovadzhennya_mediaosviti_ v_ukraini_nova_redaktsiya/. (in Ukrainian)

[13] Massachusetts Commission to Develop an Index of Creative and Innovative Education in the Public Schools, 2012. Section 181 of Chapter 240 of the Acts of 2010, amended by Chapter 9 of the Acts of 2011. Massachusetts Department of Elementary and Secondary Education. Available at: http://www.doe.mass.edu/research/reports/2012/09CIEindex.pdf.

[14] Miller S.T, Redman S.L. Enhancing student performance in an online introductory astronomy course with video demonstrations. Astronomy Education Review, 9 (1) (2010). Available at: https://doi.org/10. 3847/AER2009072.

[15] New Ukrainian School: Conceptual Principles for General School Reform (2016). Available at: https://mon.gov.ua/storage/app/media/zagalna\%20serednya/nova-ukrainska-shkola-compressed.pdf. (in Ukrainian)

[16] Richter D.M., Paretti M.C. Identifying barriers to and outcomes of interdisciplinarity in the engineering classroom. European Journal of Engineering Education, 34 (2009), 29-45. Available at: http://dx.doi.org/10. 1080/03043790802710185.

[17] Rodriguez J., Esparragoza I.E. Motivation of engineering students participating in multinational design projects - Comparison Based on Gender and Class Status. International Journal of Engineering Pedagogy, 7 (4) (2017), 78-90. Available at: https://doi.org/10.3991/ijep.v7i4.7516.

[18] Superstars of STEM. Available at: https://scienceandtechnologyaustralia.org.au/what-we-do/superstarsof-stem/.

[19] Strang D.K. Skype synchronous interaction effectiveness in a quantitative management science course. Decision Sciences Journal of Innovative Education, 10 (1) (2012), 3-23. doi: 10.1111/j.1540-4609.2011.00333.x

[20] Technology enhanced learning: Research themes. Erik Duval, Mike Sharples, Rosamund Sutherland (Editors). Springer Nature, Cham, Switzerland, 2017. ISBN: 9783319025995

[21] Yang D. Instructional strategies and course design for teaching statistics online: perspectives from online students. International Journal of STEM Education, 4 (34) (2017). Available at: https://doi.org/10. 1186/s40594-017-0096-x.

Address: Olena Budnyk, Vasyl Stefanyk Precarpathian National University, 57, Shevchenko Str., IvanoFrankivsk, 76018, Ukraine.

E-mail: olena.budnyk@pu.if.ua.

Received: 01.11.2017; revised: 22.03.2018.

Будник Олена. Теоретичні основи використання STEAM-технологій у підготовці вчителя Нової української школи. Журнал Прикарпатського університету імені Василя Стефаника, 5 (1) (2018), 23-30.

У статті обгрунтовано актуальність проблеми STЕАМ-освіти, потребу підготовки фахівців, зокрема вчителів до використання сучасних цифрових технологій у навчанні студентів, орієнтації молодого покоління на професії STEM. Автором визначено сутність цифрової компетентності 
сучасного фахівця, що включає систему знань і вмінь щодо усвідомленого, відповідального та критичного використання цифрових технологій у процесі навчально-трудової діяльності, громадянській чи соціальній активності. 3'ясовано, що цифрова компетентність учителя виявдяється у його інформаційній грамотності, культурі використання даних, комунікації в інформаційному просторі, здатності створювати відповідний цифровий контент. Висвітлено теоретичні засади впровадження інноваційних технологій у педагогічний процес Нової української школи. Представлено форми та методи використання STEAM-технологій у сучасному навчальному закладі. Наголошено на потребі використання у роботі з студентами різноманітних інструментів навчання: презентації, лабораторні підручники, моделювання, дискусії, співпраця як супровід навчальної діяльності, дослідження та ін.

Ключові слова: STEAM-освіта, цифрова компетентність, інноваційні освітні технології, електронне навчання, сучасний вчитель.

\section{î을 D}

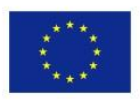

Co-funded by the Erasmus+ Programme of the European Union

«The article has been prepared in the framework of the Erasmus+ project "MoPED - Modernization of Pedagogical Higher Education by Innovative Teaching Instruments", No. 586098-EPP-1-2017-1-UA-EPPKA2CBHE-JP. This project has been funded with support from the European Commission. This publication reflects the views only of the author, and the Commission cannot be held responsible for any use which may be made of the information contained therein». 